\title{
PEMBUDAYAAN PENDIDIKAN ANTI KORUPSI DI DALAM LINGKUNGAN KELUARGA BERBASIS PEMBENTUKAN KARAKTER
}

\author{
Sri Sulistyawati ${ }^{1}$, Nelvitia Purba ${ }^{2}$, Hardi Mulyono $^{3}$, Gelora Sinaga ${ }^{4}$ \\ Universitas Muslim Nusantara (UMN) Al-Washliyah \\ Jl. Garu II No. 93 Medan \\ Ilmu Hukum ${ }^{1,2}$, Manajemen ${ }^{3}$
}

\begin{abstract}
Abstrak
Korupsi adalah merupakan suatu dari kejahatan yang luar biasa (ekstra ordinary crime), hal ini disebabkan karena korupsi terjadi di semиa bidang kehidupan, dan dilakukan secara sistematis sehingga sangat sulit untuk memberantasnya. Perbuatan korupsi merupakan suatu perbuatan orang yang tidak jujur yang bermula sebagai perbuatan jahat yang memerlukan kemampuan berpikir, dengan pola perbuatan yang demikian itu kemudian paling mudah merangsang untuk ditiru dan menjalar dalam lapisan masyarakat. Oleh karenanya tidak mengherankan bila korupsi terjadi di semua bidang kehidupan, dan dilakukan oleh semua lapisan masyarakat, baik pemerintah, maupun swasta baik pejabat maupun pegawai rendahan. Berkaitan dengan KPK yang sudah mencanangkan program kerja yang salah satunya adalah melakukan suatu upaya preventif dengan melibatkan semua unsur. Upaya preventif ini adalah dengan melakukan penanaman nilai-nilai anti korupsi terhadap semua pihak,bahakn KPK meminta sekolah dan Perguruan Tinggi dalam mata pelajaran dan mata kuliah dapat disisipkan penanaman nilai-nilai anti korupsi, dengan demikian generasi penerus bangsa diharapkan menjadi generasi anti korupsi. Hal yang sama juga dapat ditanamkan nilai-nilai anti korupsi dapat dilakukan di lingkungan keluarga melalui nilai nilai 18 karakter. Dengan menenanamkan 18 nilai nilai karakter di keluarga akan menumbuhkan nilai nilai anti korupsi dan menjadi budaya yang diterapkan dalam kehidupan sehari-hari sehingga dengan demikian dapat berpartisipasi dalam program pemerintah untuk membenrantas korupsi.
\end{abstract}

Kata Kunci : Pembudayaan, nilai-nilai karakter, keluarga, anti korupsi, pencegahan.

\begin{abstract}
Abtract
Corruption is an extraordinary crime (extra ordinary crime), this is because corruption takes place in all areas of life, and is done systematically so it is very difficult to eradicate it. The act of corruption is a dishonest act that begins as an evil deed that requires the ability to think, with such a pattern of action is then most easily stimulated to be imitated and spread within the community. It is therefore not surprising that corruption takes place in all areas of life, and is carried out by all levels of society, both government and private, whether officials or officials are lowly. In connection with the Commission which has launched a work program that one of them is to conduct a preventive effort by involving all elements. This preventive effort is to plant anticorruption values to all parties, that KPK ask schools and universities in the subjects and courses can be inserted anti-corruption values, thus the next generation is expected to become the generation of anti-corruption. The same can also be embedded anti-corruption values can be done in the family environment through the value of 18 characters. By embedding 18 values of character in the family will grow the value of anti-corruption values and become a culture that is applied in everyday life so that it can participate in government programs to eliminate corruption.
\end{abstract}

Keyword: Culture, character values, family, anti-corruption, prevention.

\section{Pendahuluan}

Korupsi adalah merupakan suatu dari kejahatan yang luar biasa (ekstra ordinary crime), hal ini disebabkan karena korupsi terjadi di semua bidang kehidupan, dan dilakukan secara sistematis sehingga sangat sulit untuk memberantasnya. Korupsi, kini sudah menjadi permasalahan serius di negeri ini. Kasus korupsi sudah tidak terhitung lagi jumlahnya. Meskipun sudah ada Komisi Pemberantasan Korupsi (KPK) 
dan beberapa Instansi anti korupsi lainnya. Namun faktanya negeri ini masih menduduki rangking atas sebagai Negara terkorup didunia. Karena dari itu, korupsi patut menjadi perhatian serius bagi kita semua.

Tindak pidana korupsi merambat ke daerah-daerah di Indonesia, tidak terkecuali di Sumatera Utara. Propinsi Sumatera Utara menjadi wilayah dengan kasus korupsi terbanyak di Indonesia. Jumlah ini berdasarkan hasil penelitian yang dilakukan oleh Indonesia ICW periode 1 Juli-31 Des. Berdasarkan data yang dilansir oleh Forum Transparansi Indonesia untuk anggaran (Fitra) wilayah Sumatera Utara dari hasil audit Badan Pemeriksa Keuangan (BPK) pada ikhtisar hasil pemeriksaan (IHP) Semester II tahun 2012. Menempatkan Sumatera Utara sebagai propinsi terkorup di Indonesia. Propinsi Sumatera Utara menduduki peringkat pertama disusul oleh Propinsi Aceh, Papua Barat, DKI Jakarta peringkat keempat.

Hal ini tentunya perlu langkah sistematis untuk menanggulanginya. Pemerintah Indonesia telah berusaha keras untuk memerangi korupsi dengan berbagai cara,Salah satunya dengan adanya KPK sebagai lembaga independen yang secara khusus menangani tindak korupsi menjadi upaya pencegahan dan penindakan tindak pidana namun belum mampu juga untuk mengurangi kejahatan korupsi yang terjadi di Indonesia pada umumnya dan di Sumatera Utara pada khususnya.

Korupsi beberapa dekade ini merupakan isu sentral dalam penegakan hukum.Berbagai upaya telah dilakukan oleh pemerintah di dalam pemberantasan korupsi ini dengan menetapkan berbagai strategi nasional lebih-lebih di era reformasi, baik melalui Instruksi Presiden Nomor 5 Tahun 2004 Tentang Percepatan Pemberantasan Korupsi, Strategi Nasional Dan Rencana Aksi Pemberantasan Korupsi (Stranas PPK) 2010-2025, Instruksi Presiden Nomor 9
Tahun 2011 Tentang Rencana Aksi Percepatan Dan Pemberantasan Korupsi 2011, Instruksi Presiden Nomor 14 Tahun 2011 Tentang Aksi Percepatan Dan Pemberantasan Korupsi Tahun 2012, Strategi Nasional Pencegahan Dan Pemberantasan Korupsi Jangka Panjang (2012-2025 dan Jangka Menengah (2012-2014).

Dalam kehidupan berbangsa dan bernegara belum tumbuh budaya mutu, budaya malu, dan budaya kerja,baik di kalangan para pemimpin maupun di kalangan masyarakat pada umumnya sehingga sulit untuk mencari tokoh atau figur yang bisa diteladani. Ini merupakan bukti terjadinya pergeseran nilai menuju kehancuran atau pembentukan nilai- nilai baru atas dasar pragmatisme, materialisme, hedonisme, sekularisme, bahkan atheisme. Korupsi sudah merambah kepada semua bidang kehidupan baik politik, sosial, ekonomi dan budaya, dilain pihak masyarakat pada umumnya tidak memiliki pengetahuan yang memadai tentang korupsi.

Bahkan kebanyakan masyarakat umumnya memiliki persepsi yang salah tentang korupsi yaitu :

1. Bahwa korupsi hanya bisa dilakukan oleh pejabat atau pegawai negeri

2. Bahwa korupsi adalah perbuatan mengambil dari uang negara

3. Bahwa korupsi adalah urusan dari penegak hukum

4. Pegawai negeri yang menerima komisi dalam pekerjaan mereka bukanlah korupsi

5. Menerima hadiah dari orang yang berurusan dengan kita (karena pekerjaan) setelah pekerjaan selesai adalah ucapan terima masih.

6. Membayar lebih untuk urusan SIM,KTP dan surat- surat lain adalah hal biasa. 
Pemahaman yang keliru tentang tindakan di atas menyebabkan, warga masyarakat tidak bisa menerima jika kemudian di antara mereka menjadi tersangka korupsi karena melakukan hal yang sudah dianggap biasa. Bambang Poernomo mengemukakan bahwa :

"Salah satu jenis kejahatan yang semakin sulit dijangkau oleh aturan pidana adalah korupsi. Perbuatan korupsi merupakan suatu perbuatan orang yang tidak jujur yang bermula sebagai perbuatan jahat yang memerlukan kemampuan berpikir, dengan pola perbuatan yang demikian itu kemudian paling mudah merangsang untuk ditiru dan menjalar dalam lapisan masyarakat. Oleh karenanya tidak mengherankan bila korupsi terjadi di semua bidang kehidupan, dan dilakukan oleh semua lapisan masyarakat, baik pemerintah, maupun swasta baik pejabat maupun pegawai rendahan.

Berkaitan dengan KPK yang sudah mencanangkan program kerja yang salah satunya adalah melakukan suatu upaya preventif dengan melibatkan semua unsur. Upaya preventif ini adalah dengan melakukan penanaman nilai-nilai anti korupsi terhadap semua pihak, bahakn KPK meminta sekolah dan Perguruan Tinggi dalam mata pelajaran dan mata kuliah dapat disisipkan penanaman nilainilai anti korupsi, dengan demikian generasi penerus bangsa diharapkan menjadi generasi anti korupsi. Hal yang sama juga dapat ditanamkan nilai-nilai anti korupsi dapat dilakukan di lingkungan keluarga melalui nilai nilai 18 karakter. Dengan menenanamkan 18 nilai nilai karakter di keluarga akan menumbuhkan nilai nilai anti korupsi dan menjadi budaya yang diterapkan dalam kehidupan sehari-hari sehingga dengan demikian dapat berpartisipasi dalam program pemerintah untuk membenrantas korupsi.

\section{METODE PELAKSANAAN}

Di dalam kegiatan ini sasarannya adalah “ Keluarga".Pertimbangan sasaran yang strategis dalam menanamkan nilai - nilai anti korupsi di lingkungan keluarga karena merupakan basis interaksi dan komunikasi yang terjalin secara emosional antara ayah, ibu dan anak dan tempat pertama dalam pembentukan dan nilai nilai karakter. Untuk melakukan kegiatan pendidikan anti korupsi ini dengan cara memberikan penyuluhan kepada ibuibu, ayah dan anak. Penyuluhan diberikan dengan mencakup materi antara antara lain:
a. Pengertian Korupsi
b. Perbuatan yang termasuk kategori korupsi beserta sanksi hukumnya.
c. Faktor-faktor penyebab korupsi
d. Nilai -nilai anti korupsi yang harus dimiliki dan ditumbuhkan, melalui 18 nilai-nilai karakter yang akan disebarluaskan di lingkungan keluarga.
e. Sikap anti korupsi yang harus dimiliki dan ditumbuhkan, serta disebarluaskan di lingkungan keluarga.

\section{HASIL}

Pada hari yang telah ditentukan TIM Pengabdian Masyarakat dari LP2M UMN AW Medan mendatangi tempat kegiatan yaitu Desa Pekan Sialang Buah Kecamatan Teluk mengkudu Kabupaten Sergai Bedagai umtuk memberikan pembekalan dalam bentuk Penyuluhan Hukum yang bertema " Pembudayaan Pendidikan Anti Korupsi Di Dalam Lingkungan Keluarga Untuk Pembentukan Karakter " Pembekalan dilakukan dengan metode ceramah yang kemudian diikuti dengan kegiatan tanya jawab dengan masyarakat dan tim dari Penyuluhan Hukum dari Fakultas Hukum UMN AW Medan. Pada saat metode ceramah yang digunakan dalam Penyuluhan Hukum ini Tim dari Fakultas Hukum UMN AW juga langsung menggunakan 
metode tanya jawab kepada masyarakat.

Pertanyaaan yang diajukan kepada para peserta penyuluhan hukum menunjukkan bahwa masih belum pahamnya mereka tentang apa yang dikatakan " Korupsi " dan cara berperan serta untuk ikut menanggulanginya. Namun mereka mengerti bahwa upaya pemberantasan dari korupsi tersebut membutuhkan kerjasama dari semua lapisan / semua pihak.yang bukan hanya pemerintah yaitu aparat penegak hukum tetapi juga masyarakat dan keluarga keluarga inti. Dari Pertanyaanpertanyaan yang diajukan oleh masyarakat tersebut tidak hanya berkaitan dengan topik kegiatan namun lekat dengan kehidupan mereka seharihari yang berkaitan dengan hukum, menginga Desa Pekan Sialang Buah yang daerahnya berdekatan dengan pantai tentunya banyak kejahatan yang terjadi.seperti Narkoba.

Karena ketidakpahaman dari Peserta yaitu Masyarakat menunjukkan bahwa upaya pemberantasan korupsi tersebut menghadapi jalan yang sangat panjang. Adalah tidak mungkin mengharapkan mereka untuk ikut serta dalam usaha untuk pemberantasan korupsi jika pemahaman tentang korupsi tersebut masih minim. Pada saat Tim Penyuluh Hukum menyampaikan tentang 18 Nilainilai karakter yang diterapkan dalam lingkungan keluarga dalam kaitannya juga dengan nilai-nilai anti korupsi pada umumnya mereka telah memahami nilainilai tersebut. Pada Umumnya mereka telah memahami 18 Nilai- Nilai Dalam Pendidikan Karakter Menurut Diknas:

\section{Religius}

Sikap dan perilaku yang patuh dalam melaksanakan ajaran agama yang dianutnya, toleran terhadap pelaksanaan ibadah agama lain, dan hidup rukun dengan pemeluk agama lain.

2. Jujur

Perilaku yang didasarkan pada upaya menjadikan dirinya sebagai orang yang selalu dapat dipercaya dalam perkataan, tindakan, dan pekerjaan.

3. Toleransi

Sikap dan tindakan yang menghargai perbedaan agama, suku, etnis, pendapat, sikap, dan tindakan orang lain yang berbeda dari dirinya.

4. Disiplin

Tindakan yang menunjukkan perilaku tertib dan patuh pada berbagai ketentuan dan peraturan.

5. Kerja Keras

Tindakan yang menunjukkan perilaku tertib dan patuh pada berbagai ketentuan dan peraturan.

6. Kreatif

Berpikir dan melakukan sesuatu untuk menghasilkan cara atau hasil baru dari sesuatu yang telah dimiliki.

7. Mandiri

Sikap dan perilaku yang tidak mudah tergantung pada orang lain dalam menyelesaikan tugas-tugas.

8. Demokratis

Cara berfikir, bersikap, dan bertindak yang menilai sama hak dan kewajiban dirinya dan orang lain.

9. Rasa Ingin Tahu

Sikap dan tindakan yang selalu berupaya untuk mengetahui lebih mendalam dan meluas dari sesuatu yang dipelajarinya, dilihat, dan didengar.

10. Semangat Kebangsaan

Cara berpikir, bertindak, dan berwawasan yang menempatkan kepentingan bangsa dan negara di atas kepentingan diri dan kelompoknya.

11. Cinta Tanah Air

Cara berpikir, bertindak, dan berwawasan yang menempatkan kepentingan bangsa dan negara di atas kepentingan diri dan kelompoknya.

12.Menghargai Prestasi

13. Sikap dan tindakan yang
mendorong 
menghasilkan sesuatu yang berguna bagi masyarakat, dan mengakui, serta menghormati keberhasilan orang lain.

14.Bersahabat/ Komunikatif Sikap dan tindakan yang mendorong dirinya untuk menghasilkan sesuatu yang berguna bagi masyarakat, dan mengakui, serta menghormati keberhasilan orang lain.

15. Cinta Damai

Sikap dan tindakan yang mendorong dirinya untuk menghasilkan sesuatu yang berguna bagi masyarakat, dan mengakui, serta menghormati keberhasilan orang lain.

16. Gemar Membaca

Kebiasaan menyediakan waktu untuk membaca berbagai bacaan yang memberikan kebajikan bagi dirinya.

17. Peduli Lingkungan

Sikap dan tindakan yang selalu berupaya mencegah kerusakan pada lingkungan alam di sekitarnya, dan mengembangkan upaya- upaya untuk memperbaiki kerusakan alam yang sudah terjadi.

18. Peduli Sosial

Sikap dan tindakan yang selalu ingin memberi bantuan pada orang lain dan masyarakat yang membutuhkan. Tanggung Jawab Sikap dan perilaku seseorang untuk melaksanakan tugas dan kewajibannya, yang seharusnya dia lakukan, terhadap diri sendiri, masyarakat, lingkungan (alam, sosial dan budaya), Negara dan Tuhan Yang Maha Esa.

Berbagai pertanyaan yang disampaikan oleh peserta dalam kegiatan Pengabdian masyarakat ini Tim berkesimpulan bahwa upaya pemberantasan korupsi masih harus melalui jalan yang panjang. Peran serta dari Keluarga untuk memberantas korupsi ini tidak dapat diharapkan timbul begitu saja tanpa adanya upaya untuk memberi contoh kepada mereka bagaimana hal itu harus dilakukan.

Diharapkan pemerintah seharusnya menjadi tauladan dalam pemberantasan korupsi. Upaya peran serta dari keluarga-keluarga ini dalam pemberantasan korupsi haruslah lahir dari kesadaran individual, yang didasari oleh nilai-nilai tertentu yang telah tertanam dalam diri keluarga (ayah, ibu dan anak). Nilai-nilai tersebut diantaranya adalah "Kejujuran". Jika seseorang bersifat jujur yang dilandasi oleh keyakinan agama mereka bahwa apapun yang mereka lakukan dilihat oleh Tuhannya maka dalam hal apa pun mereka tidak akan berbuat yang tidak jujur. Sifat ini merupakan dasar untuk menolak dari perilaku korupsi tersebut, karena korupsi berawal dari ketidak jujuran dan ketidak transparan dalam hal apapun itu.

\section{KESIMPULAN}

Dari kegiatan Penyuluhan hukum ini tentang nilai nilai anti korupsi dalam lingkungan keluarga, Tim Penyuluhan Hukum (Multidisiplin) menyimpulkan bahwa:

1. Pemahaman dan pengetahuan dari Masyarakat tentang kejahatan korupsi serta upaya dari pemberantasannya masih minim.

2. Di masyarakat tersebut ada pendapat yang keliru terhadap berbagai perbuatan yang selama ini dianggap wajar dalam hubungan masyarakat, namun kenyataannya adalah merupakan perbuatan korupsi.

3. Keinginan dari masyarakat untuk turut dalam pencegahan dan menanggulangi korupsi mengalami kendala, hal ini disebabkan karena pengetehuan yang minim dan perilaku korupsi hal yang dianggap wajar dalam masyarakat.

4. Penanaman nilai-nilai korupsi dalam kaitannya dengan pembentukan karakter terutama dalam kaitannya dengan “ Kejujuran " masih banyak tidak berjalan dalam kehidupan sehari hari. 


\section{DAFTAR PUSTAKA}

Aziz Syamsuddin, 2011, Tindak Pidana Khusus, Sinar Grafika Jakarta.

Andi Hamzah,2012, pemberantasan Korupsi Melalui Hukum Pidana Nasional Dan Internasional, PT. Raja Grafindo Persada Jakarta.

Damiyati Zuchdi, 2013, Model

Pendidikan karakter,Perpustakaan

Nasional.

Marwan Effendy, 2011, Kapita Selecta Hukum Pidana (Perkembangan Dan Isu-Isu Aktual Dalam KejahatanFinansial Dan Korupsi), Referensi Jakarta.

Martiman Prodjohamidjojo, 2001, Penerapan Pembuktian Terbalik Di Dalam Delik Korupsi,Mandar Maju Bandung.

Muchlas Samani, 2011, Konsep Dan Model Pendidikan Karakter,

PT. Remaja Rosdakarya.

Mansyur Hamdan, 2002, Pendidikan Kewarganegaraan, Gramedia Pustaka Utama Jakarta.

Peter Mahmud Marzuki, 2011, Penelitian Hukum, Kencana Prenada Media Group Jakarta. Syaiful Bakhri, 2009, Pidana Denda Dan Korupsi, Total Media

Jakarta. Suyadi, 2012, Strategi

Pembelajaran Pendidikan Karakter, PT. Remaja Rosdakarya. 